\title{
EFFECTS OF MANAGEMENT PRACTICES ON GRASSLAND BIRDS:
}

WILLET

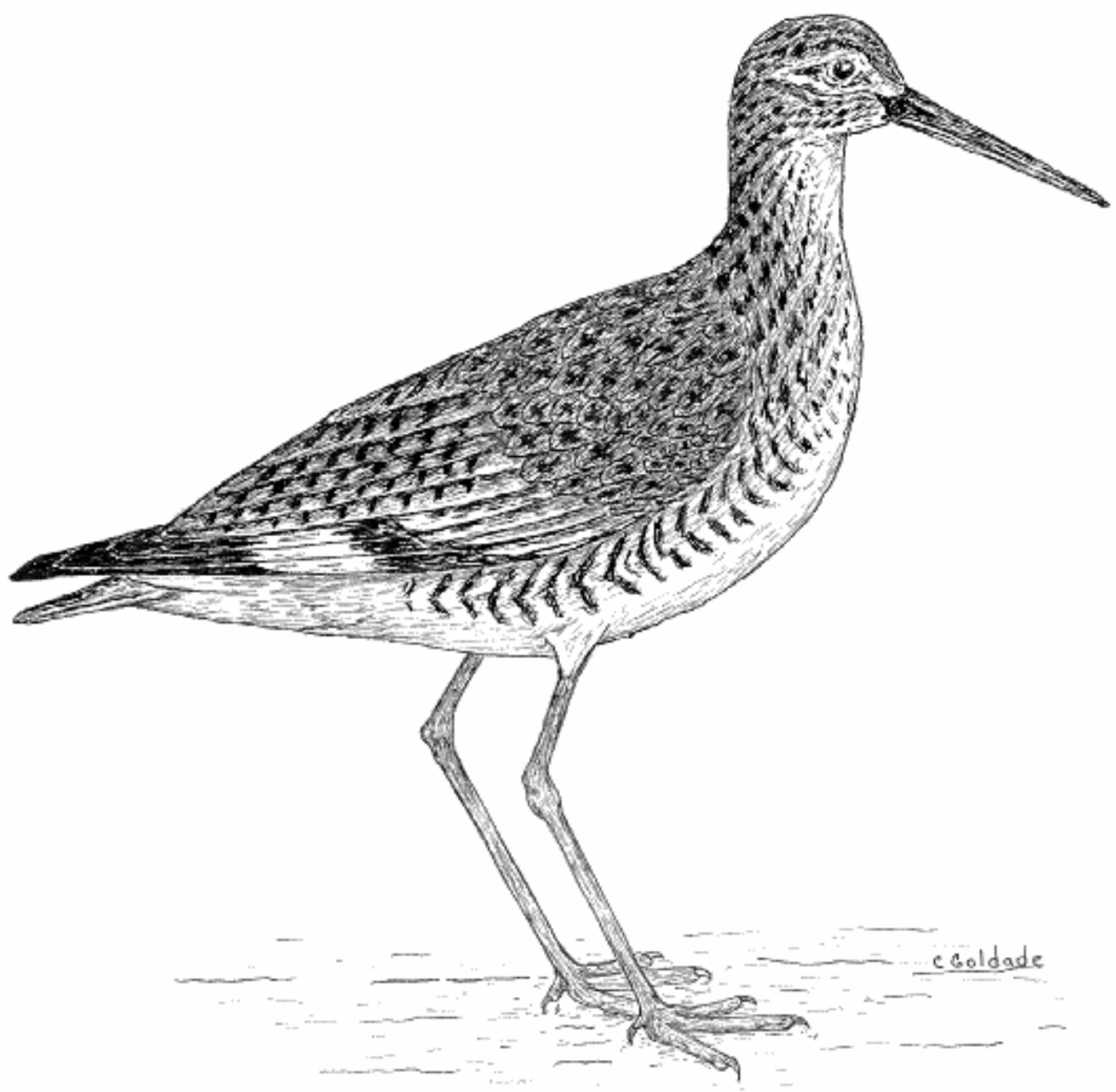

Grasslands Ecosystem Initiative

Northern Prairie Wildlife Research Center

U.S. Geological Survey

Jamestown, North Dakota 58401 
This report is one in a series of literature syntheses on North American grassland birds. The need for these reports was identified by the Prairie Pothole Joint Venture (PPJV), a part of the North American Waterfowl Management Plan. The PPJV recently adopted a new goal, to stabilize or increase populations of declining grassland- and wetland-associated wildlife species in the Prairie Pothole Region. To further that objective, it is essential to understand the habitat needs of birds other than waterfowl, and how management practices affect their habitats. The focus of these reports is on management of breeding habitat, particularly in the northern Great Plains.

Suggested citation:

Dechant, J. A., M. L. Sondreal, D. H. Johnson, L. D. Igl, C. M. Goldade, B. D. Parkin, and B. R. Euliss. 1999 (revised 2002). Effects of management practices on grassland birds: Willet. Northern Prairie Wildlife Research Center, Jamestown, ND. 13 pages .

Species for which syntheses are available or are in preparation:

American Bittern

Mountain Plover

Marbled Godwit

Long-billed Curlew

Willet

Wilson's Phalarope

Upland Sandpiper

Greater Prairie-Chicken

Lesser Prairie-Chicken

Northern Harrier

Swainson's Hawk

Ferruginous Hawk

Short-eared Owl

Burrowing Owl

Horned Lark

Sedge Wren

Loggerhead Shrike

Sprague's Pipit
Grasshopper Sparrow

Baird's Sparrow

Henslow's Sparrow

Le Conte's Sparrow

Nelson's Sharp-tailed Sparrow

Vesper Sparrow

Savannah Sparrow

Lark Sparrow

Field Sparrow

Clay-colored Sparrow

Chestnut-collared Longspur

McCown's Longspur

Dickcissel

Lark Bunting

Bobolink

Eastern Meadowlark

Western Meadowlark

Brown-headed Cowbird 


\section{EFFECTS OF MANAGEMENT PRACTICES ON GRASSLAND BIRDS:}

\section{WILLET}

Jill A. Dechant, Marriah L. Sondreal, Douglas H. Johnson, Lawrence D. Igl, Christopher M. Goldade, Barry D. Parkin, and Betty R. Euliss

Series Coordinator: Douglas H. Johnson

Series Assistant Coordinator: Lawrence D. Igl

Reviewer: James J. Dinsmore

Range Map: Jeff T. Price

Cover Art: Christopher M. Goldade

Major Funding: Prairie Pothole Joint Venture, U.S. Fish and Wildlife Service U.S. Geological Survey

Funding also provided by: U.S. Forest Service The Nature Conservancy

\section{Collaborators:}

Louis B. Best, Iowa State University

Carl E. Bock, University of Colorado

Brenda C. Dale, Canadian Wildlife Service

Stephen K. Davis, Saskatchewan Wetland Conservation Corporation

James J. Dinsmore, Iowa State University

James K. Herkert, Illinois Endangered Species Protection Board

Fritz L. Knopf, Midcontinent Ecological Science Center

Rolf R. Koford, Iowa Cooperative Fish and Wildlife Research Unit

David R. C. Prescott, Alberta NAWMP Centre

Mark R. Ryan, University of Missouri

David W. Sample, Wisconsin Department of Natural Resources

David A. Swanson, Ohio Division of Wildlife

Peter D. Vickery, Massachusetts Audubon Society

John L. Zimmerman (retired), Kansas State University

March 1999

(revised January 2002) 


\section{ORGANIZATION AND FEATURES OF THIS SPECIES ACCOUNT}

Information on the habitat requirements and effects of habitat management on grassland birds were summarized from information in more than 4,000 published and unpublished papers. A range map is provided to indicate the relative densities of the species in North America, based on Breeding Bird Survey (BBS) data. Although birds frequently are observed outside the breeding range indicated, the maps are intended to show areas where managers might concentrate their attention. It may be ineffectual to manage habitat at a site for a species that rarely occurs in an area. The species account begins with a brief capsule statement, which provides the fundamental components or keys to management for the species. A section on breeding range outlines the current breeding distribution of the species in North America, including areas that could not be mapped using BBS data. The suitable habitat section describes the breeding habitat and occasionally microhabitat characteristics of the species, especially those habitats that occur in the Great Plains. Details on habitat and microhabitat requirements often provide clues to how a species will respond to a particular management practice. A table near the end of the account complements the section on suitable habitat, and lists the specific habitat characteristics for the species by individual studies. A special section on prey habitat is included for those predatory species that have more specific prey requirements. The area requirements section provides details on territory and home range sizes, minimum area requirements, and the effects of patch size, edges, and other landscape and habitat features on abundance and productivity. It may be futile to manage a small block of suitable habitat for a species that has minimum area requirements that are larger than the area being managed. The Brown-headed Cowbird (Molothrus ater) is an obligate brood parasite of many grassland birds. The section on cowbird brood parasitism summarizes rates of cowbird parasitism, host responses to parasitism, and factors that influence parasitism, such as nest concealment and host density. The impact of management depends, in part, upon a species' nesting phenology and biology. The section on breeding-season phenology and site fidelity includes details on spring arrival and fall departure for migratory populations in the Great Plains, peak breeding periods, the tendency to renest after nest failure or success, and the propensity to return to a previous breeding site. The duration and timing of breeding varies among regions and years. Species' response to management summarizes the current knowledge and major findings in the literature on the effects of different management practices on the species. The section on management recommendations complements the previous section and summarizes specific recommendations for habitat management provided in the literature. If management recommendations differ in different portions of the species' breeding range, recommendations are given separately by region. The literature cited contains references to published and unpublished literature on the management effects and habitat requirements of the species. This section is not meant to be a complete bibliography; a searchable, annotated bibliography of published and unpublished papers dealing with habitat needs of grassland birds and their responses to habitat management is posted at the Web site mentioned below.

This report has been downloaded from the Northern Prairie Wildlife Research Center WorldWide Web site, www.npwrc.usgs.gov/resource/literatr/grasbird/grasbird.htm. Please direct comments and suggestions to Douglas H. Johnson, Northern Prairie Wildlife Research Center, U.S. Geological Survey, 8711 37th Street SE, Jamestown, North Dakota 58401; telephone: 701253-5539; fax: 701-253-5553; e-mail: Douglas_H_Johnson@usgs.gov. 
WILLET

(Catoptrophorus semipalmatus inornatus)

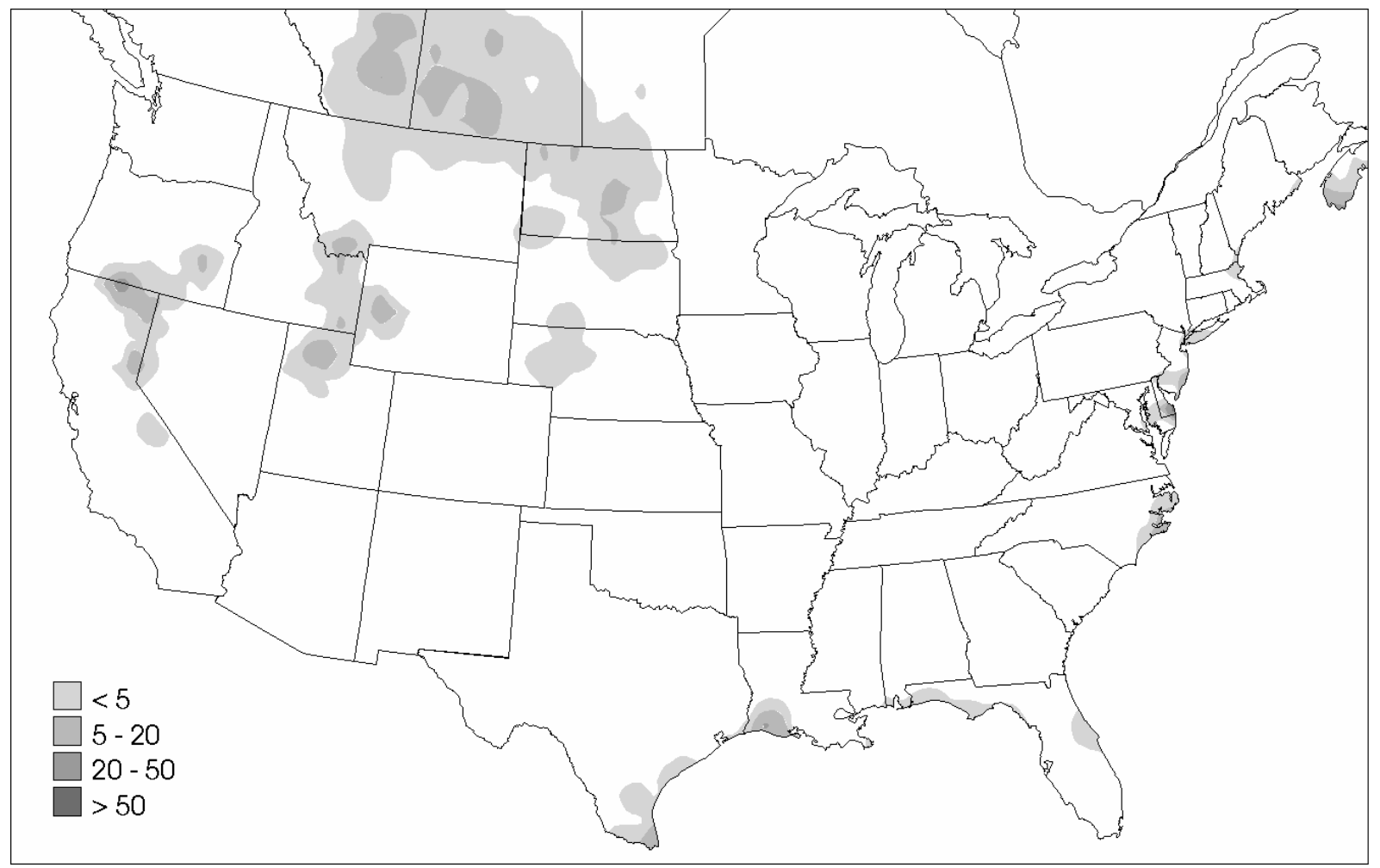

Figure. Breeding distribution of the Willet in the United States and southern Canada, based on Breeding Bird Survey data, 1985-1991. Scale represents average number of individuals detected per route per year. Map from Price, J., S. Droege, and A. Price. 1995. The summer atlas of North American birds. Academic Press, London, England. 364 pages.

Keys to management include providing large expanses of native grasslands and wetland complexes. Wetland complexes contain a diversity of wetland classes and sizes, such as ephemeral, temporary, seasonal, semipermanent, and permanent wetlands, as well as intermittent streams. Willets use wetlands of various salinities. Willets require short, sparse upland grasslands for nesting and foraging and wetland complexes for foraging. Broods use taller, denser grass cover than do nesting adults.

\section{Breeding range:}

Two subspecies of Willets breed in North America: the eastern Willet (Catoptrophorus semipalmatus semipalmatus) and the western Willet (C. s. inornatus). This account deals only with the subspecies of Willet that breeds on the Great Plains, the western Willet, and not with the eastern Willet, which breeds on the Atlantic and Gulf coasts of North America. Western Willets breed from central Alberta and Montana through southern Manitoba, North Dakota, western Minnesota, and South Dakota, south to southcentral Oregon and central California, and east to northern Nevada, Idaho, northern Utah, Wyoming, northern Colorado, and western Nebraska (National Geographic Society 1987). (See figure for the relative densities of Willets in the United States and southern Canada, based on Breeding Bird Survey data.) 


\section{Suitable habitat:}

Breeding Willets require large expanses of short, sparse grasslands for nesting and foraging, and wetland complexes for foraging (Stewart 1975; Weber 1978; Kantrud and Stewart 1984; Ryan and Renken 1987; Colwell and Oring 1988a, 1990; Kantrud and Higgins 1992; Prescott et al. 1995). In both upland and wetland habitats, adults with broods use somewhat taller, denser grass cover than do breeding pairs during nesting (Ryan and Renken 1987). In North Dakota, uplands used by Willets had a thinner litter layer than surrounding areas (Renken 1983). They often nest near a conspicuous object such as a piece of wood, dried cattle dung, or a stone (Higgins et al. 1979, Kantrud and Higgins 1992).

Willets prefer native grass to tame vegetation (Stewart 1975, Ryan and Renken 1987, Kantrud and Higgins 1992). They prefer pastures that are idle during the nesting season, and to a lesser extent actively grazed pasture, to other land-use types (Higgins et al. 1979, Ryan and Renken 1987, Kantrud and Higgins 1992). Although tilled lands usually are avoided (Weber 1978), nests have been reported in hayland and cropland, including small-grain, flax, and stubble fields (Higgins et al. 1979, Kantrud and Higgins 1992). In North Dakota, pairs nesting in native vegetation had higher hatching success than pairs nesting in cultivated fields (Higgins et al. 1979). In the prairie and aspen parkland regions of Alberta, mean number of birds/site was nonstatistically compared among several habitats (Prescott et al. 1995, Prescott 1997). In prairie, Willets were most abundant in native mixed-grass, followed by coulee, upland shrub, planted cropland, and hayland (Prescott 1997). Coulee was defined as a valley containing an ephemeral creek or seepage that may contain other, undescribed, habitat types. Hayland was planted to grasses (species not given) or alfalfa (Medicago sativa). In the uplands of aspen parkland, Willets were most abundant in deferred native pastures grazed after 15 July, followed by idle native grassland, continuously grazed native parkland, and tame dense nesting cover (Prescott et al. 1995). They were not found in tame pasture, deferred tame pasture, idle tame uplands, idle tame grasslands, continuously grazed native grasslands, idle parkland, or native dense nesting cover.

In wetlands, Willets avoid dense, emergent vegetation, preferring shallow-water areas with short, sparse shoreline vegetation (Ryan and Renken 1987, Colwell and Oring 1988a, Eldridge 1992). Suitable wetlands range in salinity from fresh to saline, and vary widely in size and permanence (Stewart and Kantrud 1965, Stewart 1975, Kantrud and Stewart 1984, Ryan and Renken 1987, Prescott et al. 1995, Eldridge 1992). In North Dakota, Willets were more common in alkali or permanent wetlands than in temporary, seasonal, or semipermanent wetlands (D. H. Johnson et al., unpublished data). Shifts in wetland use occur seasonally and during climatic extremes (Ryan and Renken 1987, Gratto-Trevor 1999). Semipermanent wetlands were used most often, but ephemeral, temporary, seasonal, and alkali ponds were preferred relative to their availability (Ryan and Renken 1987). Semipermanent wetlands were used later in the summer than other wetland types. Semipermanent and permanent wetlands were used during drought years. A table near the end of the account lists the specific habitat characteristics for Willets by study.

\section{Area requirements:}

Willet territories are large and include both feeding and nesting areas. Areas must be large enough to provide both upland habitat and a diversity of wetland types (Kantrud and 
Stewart 1984, Ryan and Renken 1987, Colwell and Oring 1988a). In North Dakota, mean territory size was 44.3 ha (Ryan and Renken 1987). Willets may be area sensitive, rarely occurring on blocks of contiguous grassland $<100$ ha in the northern Great Plains (D. H. Johnson, unpublished data).

Brown-headed Cowbird brood parasitism:

No known records of brood parasitism by Brown-headed Cowbirds (Molothrus ater) exist.

Breeding-season phenology and site fidelity:

Willets arrive on Saskatchewan breeding grounds from late April to mid-May, and depart from mid-August to early September (Maher 1974). In the northern Great Plains, Willets breed from early May through late July, with broods present from about early June until late July (Stewart 1975, Kantrud and Higgins 1992, Sedivec 1994). Ryan et al. (1981) reported two cases of renesting after initial nests were destroyed. In Saskatchewan, adults of both sexes and juvenile females exhibited breeding-site fidelity (Colwell and Oring 1988b). In New York, a male Willet was recaptured eight years later in the same general area in which he was banded (Clapp et al. 1982).

Species' response to management:

Ryan and Renken (1987) recommended burning, mowing, or grazing of both upland and wetland habitat to maintain the short, sparse vegetation and thin litter layer preferred by Willets. Little specific information is available about the effects of prescribed burning or haying; Willet densities were unrelated to time since burning in a North Dakota grassland study (Johnson 1997). Ryan et al. (1984) suggested that fall burning can provide dense, taller regrowth (15-60 $\mathrm{cm}$ ) later in the summer; broods used vegetation $>15 \mathrm{~cm}$ (Ryan and Renken 1987).

Grazed uplands often are more attractive to breeding Willets than are idle grasslands (Messmer 1985, 1990; Renken and Dinsmore 1987; Kantrud and Higgins 1992, Sedivec 1994). In Alberta, Willet densities were higher (not statistically tested) on deferred native pastures than on native pastures grazed in early summer, but were not present on continuously grazed native pastures (Prescott and Wagner 1996). However, they were present on tame pastures of crested wheatgrass (Agropyron cristatum) grazed in spring from late April to mid-June. In Saskatchewan, Willets were observed on both grazed and ungrazed areas (Dale 1984).

In North Dakota, densities of breeding Willets were significantly higher on the twiceover deferred grazing system than on season-long or short-duration grazing systems, or on idle pastures (Messmer 1990). Twice-over rotation involves grazing a number of pastures twice per season, with about a 2-mo rest between grazing. Season-long grazing involves leaving cattle on the same pasture for the entire growing season. Short-duration grazing involves a system of pastures rotated through a grazing schedule of about 1 wk grazed and 1 mo ungrazed, repeated throughout the growing season (usually late May or early June until October). The twice-over deferred pastures were composed of silty range, thin upland range, and shallow-to-gravel range sites (Messmer 1990, Sedivec 1994). Silty range and thin upland range sites were characterized by thin topsoil, loamy soil, 1-25\% slope, grassy cover, low shrub cover, and moderate to high litter cover. Maximum vegetation height ranged from 50 to $70 \mathrm{~cm}$ and average litter depth 
ranged from 3.8 to $9.1 \mathrm{~cm}$. Shallow-to-gravel range sites were characterized by sparse cover and reduced litter.

\section{Management Recommendations:}

Provide a diversity of wetlands (Kantrud and Stewart 1984, Ryan et al. 1984, Ryan and Renken 1987, Colwell and Oring 1988a). Willets use wetlands of widely varying types and salinity, and may need to use larger, more permanent, wetlands during droughts or in late summer (Ryan and Renken 1987, Prescott et al. 1995).

Protect wetlands from drainage (Ryan et al. 1984, Ryan and Renken 1987) and restore drained wetlands (Berkey et al. 1993, Johnson 1996).

Provide native grassland habitat for upland nesting and foraging (Ryan and Renken 1987, Eldridge 1992, Kantrud and Higgins 1992).

Protect wetland and grassland habitats such that they are extensive enough to support Willet territories, which averaged 44.3 ha in North Dakota (Ryan and Renken 1987). Willets were not found in small (<100 ha) blocks of wetland and grassland habitat (Ryan and Renken 1987; D.H. Johnson, unpublished data). Areas also must be large enough to provide both grassland habitat and a diverse range of wetland types and sizes (Stewart 1975, Kantrud and Stewart 1984, Ryan and Renken 1987, Colwell and Oring 1988a, Kantrud and Higgins 1992).

Burning, mowing, and grazing can be used to provide areas of shorter, sparser vegetation in uplands and wetlands (Kantrud and Stewart 1984, Messmer 1985, Ryan and Renken 1987, Eldridge 1992, Berkey et al. 1993). Fall burning or mowing of upland sites and wetland edges can produce suitable cover for the following spring (Ryan et al. 1984). Moderate to dense regrowth in burned areas may be too dense for nesting, but may provide the denser, taller cover used by broods (Ryan et al. 1984).

Choose a rotational grazing system, such as twice-over deferred grazing, over a season-long grazing system (Messmer 1985, 1990; Sedivec 1994). Berkey et al. (1993) suggested that shortterm grazing (2-4 wk in May) may be beneficial to Willets in North Dakota. Willets prefer previously grazed areas that are idle during the current breeding season (Kantrud and Higgins 1992).

Delay grazing until late May to early June when implementing a rotational grazing system; grazing should be delayed until mid-June when implementing season-long grazing (Sedivec 1994).

Protect grasslands from tilling (Ryan et al. 1984, Ryan and Renken 1987). Encourage no-tillage and minimum-tillage practices on cropland (Kantrud and Higgins 1992). 
Newly-developed livestock or surface-mine impoundments should have minimum parameters of 0.6 ha surface area, $40 \%$ area in shallow water ( $\leq 1 \mathrm{~m}$ deep), $1500 \mathrm{stems} / \mathrm{m}^{2}$ vegetation density in shallow areas, $0.6 \mathrm{mg} / \mathrm{L}$ nitrogen content, $0.07 \mathrm{mg} / \mathrm{L}$ phosphorus content, and a well-developed shoreline (Uresk and Severson 1988). 
Table. Willet habitat characteristics.

\begin{tabular}{|c|c|c|c|}
\hline Author(s) & Location(s) & Habitat(s) Studied* & Species-specific Habitat Characteristics \\
\hline $\begin{array}{l}\text { Colwell and Oring } \\
1988 a, 1990\end{array}$ & Saskatchewan & $\begin{array}{l}\text { Mixed-grass/tame } \\
\text { pasture, wetland, } \\
\text { wet-meadow pasture }\end{array}$ & $\begin{array}{l}\text { Nested in wetland margins and upland pasture with short, } \\
\text { sparse vegetation; waded in shallow water within } 10 \mathrm{~m} \text { of } \\
\text { the wetland edge }\end{array}$ \\
\hline Eldridge 1992 & Midwest & $\begin{array}{l}\text { Burned, cropland, } \\
\text { idle, idle grassland, } \\
\text { idle seeded-native, } \\
\text { hayland, pasture, } \\
\text { wetland complex }\end{array}$ & $\begin{array}{l}\text { Used short ( }<15 \mathrm{~cm} \text { high), sparse grassland for nesting and } \\
\text { feeding; preferred native vegetation and avoided tilled } \\
\text { cropland; required wetland complex to provide sparsely } \\
\text { vegetated shorelines for foraging }\end{array}$ \\
\hline Gratto-Trevor 1999 & Alberta & $\begin{array}{l}\text { Shortgrass pasture, } \\
\text { wetland }\end{array}$ & $\begin{array}{l}\text { Were present in areas with shallow water, a condition that } \\
\text { was provided by created wetlands but not natural wetlands, } \\
\text { which were dry during the study }\end{array}$ \\
\hline Higgins et al. 1979 & North Dakota & $\begin{array}{l}\text { Burned mixed-grass, } \\
\text { cropland, idle mixed- } \\
\text { grass, idle tame, } \\
\text { mixed-grass pasture }\end{array}$ & $\begin{array}{l}\text { Nested in short grasses, often near an object such as wood, } \\
\text { dried cattle dung, or a stone; also nested in cropland } \\
\text { including small-grain, flax, and stubble fields; nesting } \\
\text { success was higher in grasslands than in cultivated fields }\end{array}$ \\
\hline $\begin{array}{l}\text { Kantrud and Higgins } \\
1992\end{array}$ & $\begin{array}{l}\text { Manitoba, } \\
\text { Montana, } \\
\text { North Dakota, } \\
\text { South Dakota }\end{array}$ & $\begin{array}{l}\text { Burned mixed-grass, } \\
\text { cropland, hayland, } \\
\text { idle mixed-grass, idle } \\
\text { tame, mixed-grass } \\
\text { pasture }\end{array}$ & $\begin{array}{l}\text { Nested in native and tame grasslands, cropland, pastures, } \\
\text { hayland, and idle or burned areas; preferred nesting in native } \\
\text { grasslands and pastures that were idle during the current } \\
\text { growing season; dominant vegetation at nest sites included } \\
\text { green needlegrass (Stipa viridula), short sedges (Carex spp.), } \\
\text { and Kentucky bluegrass (Poa pratensis); most nest sites } \\
\text { were characterized by grassy vegetation with effective } \\
\text { vegetation height }<15 \mathrm{~cm}, 15 \% \text { forb cover, }>40 \% \text { dead } \\
\text { vegetation, } 100 \% \text { visual obstruction at }<5 \mathrm{~cm} \text {; a few nest } \\
\text { sites were dominated by forbs, bare ground, rocks, or cow } \\
\text { dung }\end{array}$ \\
\hline
\end{tabular}




\begin{tabular}{|c|c|c|c|}
\hline $\begin{array}{l}\text { Kantrud and Stewart } \\
1984\end{array}$ & North Dakota & Wetland complex & $\begin{array}{l}\text { Were present in fens, and seasonal, temporary, } \\
\text { semipermanent, permanent, and alkali wetlands }\end{array}$ \\
\hline Messmer 1985, 1990 & North Dakota & $\begin{array}{l}\text { Idle mixed- } \\
\text { grass/tame, mixed- } \\
\text { grass/tame hayland, } \\
\text { mixed-grass/tame } \\
\text { pasture }\end{array}$ & $\begin{array}{l}\text { Highest breeding densities were on twice-over deferred } \\
\text { pastures (grazed twice per season with 2-mo rest between } \\
\text { grazing) than season-long (leaving cattle on the same pasture } \\
\text { all season), short-duration (system of pastures rotated } \\
\text { through a grazing schedule of about } 1 \text { wk), or idle pastures; } \\
\text { density decreased as range conditions improved on a } \\
\text { managed pasture; did not use idle areas even after they were } \\
\text { hayed }\end{array}$ \\
\hline Prescott 1997 & Alberta & $\begin{array}{l}\text { Cropland, hayland, } \\
\text { mixed-grass pasture, } \\
\text { shrubland, tame } \\
\text { pasture, woodland }\end{array}$ & $\begin{array}{l}\text { Were most abundant in native mixed-grass, followed by } \\
\text { coulees, upland shrub, planted cropland, and hayland }\end{array}$ \\
\hline Prescott et al. 1995 & Alberta & $\begin{array}{l}\text { Cropland, dense } \\
\text { nesting cover (DNC; } \\
\text { idle seeded-native, } \\
\text { idle tame), idle } \\
\text { mixed-grass, idle } \\
\text { parkland, idle tame, } \\
\text { mixed-grass pasture, } \\
\text { parkland pasture, } \\
\text { tame hayland, tame } \\
\text { pasture, wetland, } \\
\text { woodland }\end{array}$ & $\begin{array}{l}\text { In wetlands, Willets were most abundant in large saline } \\
\text { wetlands and rare in small freshwater wetlands; also were } \\
\text { found in medium and large freshwater and medium saline } \\
\text { wetlands; in uplands, Willets were most abundant in } \\
\text { deferred native pastures, followed by idle native grassland, } \\
\text { continuously grazed native parkland, and tame DNC; they } \\
\text { were not present in tame pasture, deferred tame pasture, idle } \\
\text { tame uplands, idle tame grasslands, idle native parkland, } \\
\text { native DNC, or continuously grazed native grasslands }\end{array}$ \\
\hline $\begin{array}{l}\text { Prescott and Wagner } \\
1996\end{array}$ & Alberta & $\begin{array}{l}\text { Mixed-grass pasture, } \\
\text { tame pasture }\end{array}$ & $\begin{array}{l}\text { Density was higher (not statistically tested) on the deferred } \\
\text { native pastures than on native pastures grazed in early } \\
\text { summer or on tame pastures; were not present on } \\
\text { continuously grazed native pastures }\end{array}$ \\
\hline
\end{tabular}




\begin{tabular}{|l|l|l|l|}
\hline $\begin{array}{l}\text { Renken 1983, } \\
\text { Renken and Dinsmore } \\
1987\end{array}$ & North Dakota & $\begin{array}{l}\text { DNC (idle tame), idle } \\
\text { mixed-grass, mixed- } \\
\text { grass pasture }\end{array}$ & $\begin{array}{l}\text { Density was significantly higher in grazed mixed-grass than } \\
\text { in idle mixed-grass; were absent from tame DNC; chose } \\
\text { areas with a thinner litter layer than unused areas; mean } \\
\text { vegetation values for used areas were 55.1\% grass cover, } \\
\text { 20.5\% forb cover, 98.7\% litter cover, 3.9\% shrub cover, } \\
0.6 \% \text { bare ground, 8.0 cm effective height, and 1.8 cm litter } \\
\text { depth }\end{array}$ \\
\hline $\begin{array}{l}\text { Ryan and Renken } \\
1987\end{array}$ & North Dakota & $\begin{array}{l}\text { Cropland, idle } \\
\text { mixed-grass, idle } \\
\text { tame, mixed-grass } \\
\text { hayland, mixed-grass } \\
\text { pasture, tame } \\
\text { hayland, tame } \\
\text { pasture, wetland } \\
\text { complex }\end{array}$ & $\begin{array}{l}\text { Nesting pairs used upland sites characterized by short }(<15 \\
\text { cm), native grass cover; preferred ephemeral, temporary, } \\
\text { seasonal, and alkali wetlands over semipermanent and } \\
\text { permanent wetlands; broods used taller ( }>15 \text { cm), denser } \\
\text { vegetation in uplands and wetlands; mean cover percentages } \\
\text { at nests were 14.5\% bare soil, 77.7\% vegetation }<15 \text { cm, } \\
7.8 \% \text { vegetation } 15-60 \text { cm tall, and 0.7\% vegetation }>60 \text { cm } \\
\text { tall; mean territory size was 44.3 ha }\end{array}$ \\
\hline Sedivec 1994 & North Dakota & $\begin{array}{l}\text { Idle mixed-grass, } \\
\text { mixed-grass pasture }\end{array}$ & $\begin{array}{l}\text { Nested in dry upland; were more common in grazed areas } \\
\text { than ungrazed areas; nested in vegetation with low height } \\
\text { density (<6 cm) }\end{array}$ \\
\hline Stewart 1975 & North Dakota & $\begin{array}{l}\text { Cropland, idle } \\
\text { mixed-grass, idle } \\
\text { shortgrass, mixed- } \\
\text { grass hayland, } \\
\text { shortgrass hayland, } \\
\text { tame hayland, } \\
\text { wetland complex }\end{array}$ & $\begin{array}{l}\text { Nested most often in native prairie; used a variety of wetland } \\
\text { types, including 47\% semipermanent, 43\% seasonal, 4\% } \\
\text { permanent, 3\% alkali, and 3\% intermittent streams; wetlands } \\
\text { used varied in salinity from fresh to highly saline; highest } \\
\text { densities were on brackish and subsaline semipermanent } \\
\text { ponds and lakes }\end{array}$ \\
& &
\end{tabular}




\begin{tabular}{|l|l|l|l|}
\hline $\begin{array}{l}\text { Stewart and Kantrud } \\
1965\end{array}$ & North Dakota & Wetland & $\begin{array}{l}\text { Highest densities were found in brackish and saline } \\
\text { semipermanent potholes with closed stands of emergent } \\
\text { cover, with clumps of emergent cover interspersed with open } \\
\text { water, or with peripheral bands of emergent cover encircling } \\
\text { expanses of open water }\end{array}$ \\
\hline $\begin{array}{l}\text { Weber 1978, } \\
\text { Weber et al. 1982 }\end{array}$ & South Dakota & $\begin{array}{l}\text { Cropland, idle } \\
\text { mixed-grass, idle } \\
\text { shortgrass, idle } \\
\text { tallgrass, mixed-grass } \\
\text { pasture, shortgrass } \\
\text { pasture, tallgrass } \\
\text { pasture, tame } \\
\text { hayland, wetland, } \\
\text { woodland }\end{array}$ & $\begin{array}{l}\text { Presence was positively associated with semipermanent, } \\
\text { seasonal, and temporary wetlands, and area of surface water; } \\
\text { presence was negatively associated with tall vegetation and } \\
\text { area of land under cultivation; also were observed in } \\
\text { ephemeral wetlands, stock ponds, intermittent streams, and } \\
\text { dugouts }\end{array}$ \\
\hline
\end{tabular}

*In an effort to standardize terminology among studies, various descriptors were used to denote the management or type of habitat. "Idle" used as a modifier (e.g., idle tallgrass) denotes undisturbed or unmanaged (e.g., not burned, mowed, or grazed) areas. "Idle" by itself denotes unmanaged areas in which the plant species were not mentioned. Examples of "idle" habitats include weedy or fallow areas (e.g., oldfields), fencerows, grassed waterways, terraces, ditches, and road rights-of-way. "Tame" denotes introduced plant species (e.g., smooth brome [Bromus inermis]) that are not native to North American prairies. "Hayland" refers to any habitat that was mowed, regardless of whether the resulting cut vegetation was removed. "Burned" includes habitats that were burned intentionally or accidentally or those burned by natural forces (e.g., lightning). In situations where there are two or more descriptors (e.g., idle tame hayland), the first descriptor modifies the following descriptors. For example, idle tame hayland is habitat that is usually mowed annually but happened to be undisturbed during the year of the study. 


\section{LITERATURE CITED}

Berkey, G., R. Crawford, S. Galipeau, D. Johnson, D. Lambeth, and R. Kreil. 1993. A review of wildlife management practices in North Dakota: effects on nongame bird populations and habitats. Report submitted to Region 6. U.S. Fish and Wildlife Service, Denver, Colorado. 51 pages.

Clapp, R. B., M. K. Klimkiewicz, and J. H. Kennard. 1982. Longevity records of North American birds: gaviidae through alcidae. Journal of Field Ornithology 53:81-124.

Colwell, M. A., and L. W. Oring. 1988a. Habitat use by breeding and migrating shorebirds in southcentral Saskatchewan. Wilson Bulletin 100:554-566.

Colwell, M. A., and L. W. Oring. 1988b. Return rates of prairie shorebirds: sex and species differences. Wader Study Group Bulletin 55:21-24.

Colwell, M. A., and L. W. Oring. 1990. Nest site characteristics of prairie shorebirds. Canadian Journal of Zoology 68:297-302.

Eldridge, J. 1992. Management of habitat for breeding and migrating shorebirds in the Midwest. U.S. Fish and Wildlife Service Leaflet 13.2.14. 6 pages.

Gratto-Trevor, C. 1999. Use of managed and natural wetlands by upland breeding shorebirds in southern Alberta. Pages 252-259 in Proceedings of the fifth prairie conservation and endangered species conference. Natural History Occasional Paper 24. Provincial Museum of Alberta, Edmonton, Alberta.

Higgins, K. F., L. M. Kirsch, M. R. Ryan, and R. B. Renken. 1979. Some ecological aspects of Marbled Godwits and Willets in North Dakota. Prairie Naturalist 11:115-118.

Johnson, D. H. 1996. Management of northern prairies and wetlands for the conservation of Neotropical migratory birds. Pages 53-67 in F. R. Thompson, III, editor. Management of midwestern landscapes for the conservation of Neotropical migratory birds. U.S.D.A. Forest Service General Technical Report NC-187.

Johnson, D. H. 1997. Effects of fire on bird populations in mixed-grass prairie. Pages 181-206 in F. L. Knopf and F. B. Samson, editors. Ecology and conservation of Great Plains vertebrates. Springer-Verlag, New York, New York.

Kantrud, H. A., and K. F. Higgins. 1992. Nest and nest site characteristics of some groundnesting, non-passerine birds of northern grasslands. Prairie Naturalist 24:67-84.

Kantrud, H. A., and R. E. Stewart. 1984. Ecological distribution and crude density of breeding birds on prairie wetlands. Journal of Wildlife Management 48:426-437.

Maher, W. J. 1974. Matador Project: Birds II. Avifauna of the Matador area. Canadian Committee for the International Biological Programme, Matador Project, Technical Report 58. University of Saskatchewan, Saskatoon, Saskatchewan. 31 pages. 
National Geographic Society. 1987. Field guide to the birds of North America, second edition. National Geographic Society, Washington, D.C. 464 pages.

Prescott, D. R. C. 1997. Avian communities and NAWMP habitat priorities in the northern prairie biome of Alberta. NAWMP-029. Land Stewardship Centre of Canada, St. Albert, Alberta. 41 pages.

Prescott, D. R. C., A. J. Murphy, and E. Ewaschuk. 1995. An avian community approach to determining biodiversity values of NAWMP habitats in the aspen parkland of Alberta. NAWMP-012. Alberta NAWMP Centre, Edmonton, Alberta. 58 pages.

Prescott, D. R. C., and G. M. Wagner. 1996. Avian responses to implementation of a complementary/rotational grazing system by the North American Waterfowl Management Plan in southern Alberta: the Medicine Wheel Project. NAWMP-018. Alberta NAWMP Centre, Edmonton, Alberta. 24 pages.

Renken, R. B. 1983. Breeding bird communities and bird-habitat associations on North Dakota waterfowl production areas of three habitat types. M.S. thesis. Iowa State University, Ames, Iowa. 90 pages.

Renken, R. B., and J. J. Dinsmore. 1987. Nongame bird communities on managed grasslands in North Dakota. Canadian Field-Naturalist 101:551-557.

Ryan, M. R., J. J. Dinsmore, and R. B. Dahlgren. 1981. Ecology of Willets and Marbled Godwits in the glaciated prairie region. U.S. Fish and Wildlife Service, Northern Prairie Wildlife Research Center, Project 2170. 3 pages.

Ryan, M. R., and R. B. Renken. 1987. Habitat use by breeding Willets in the northern Great Plains. Wilson Bulletin 99:175-189.

Ryan, M. R., R. B. Renken, and J. J. Dinsmore. 1984. Marbled Godwit habitat selection in the northern prairie region. Journal of Wildlife Management 48:1206-1218.

Sedivec, K. K. 1994. Grazing treatment effects on and habitat use of upland nesting birds on native rangeland. Ph.D. dissertation. North Dakota State University, Fargo, North Dakota. 124 pages.

Stewart, R. E. 1975. Breeding birds of North Dakota. Tri-College Center for Environmental Studies, Fargo, North Dakota. 295 pages.

Stewart, R. E., and H. A. Kantrud. 1965. Ecological studies of waterfowl populations in the prairie potholes of North Dakota. U.S. Fish and Wildlife Service, Bureau of Sport Fisheries and Wildlife. 1965 Progress Report. 14 pages.

Weber, M. J. 1978. Non-game birds in relation to habitat variation on South Dakota wetlands. M.S. thesis. South Dakota State University, Brookings, South Dakota. 54 pages. 
Weber, M. J., P. A. Vohs, Jr., and L. D. Flake. 1982. Use of prairie wetlands by selected bird species in South Dakota. Wilson Bulletin 94:550-554. 